\title{
Biogeography of the Llanos de Moxos: natural and anthropogenic determinants
}

\author{
Roberto Langstroth Plotkin, South Riding
}

\section{Introduction}

Prior to the arrival of Europeans in the Americas, the human inhabitants of the Llanos de Moxos constructed diverse earthworks such as mounds and causeways, raised agricultural fields in the savannas and managed the landscape using fire and other tools (DENEvan 1966; Langstroth 1996; Lombardo \& Prümers 2010; LOMBARDO et al. 2011). ERICKSON (2008) considers the Llanos de Moxos to be an example of an Amazonian «domesticated landscape» and, based on evidence from Moxos, claims that «nature in Amazonia more closely resembles a garden than a pristine, natural wilderness.» These arguments presume that Moxos is representative of Amazonia and also discount the roles of longer-term physical and biological processes in play since the Miocene when extensive non-forest ecosystems originated east of the Andean Cordillera (cf. Hoorn et al. 2010; Latrubesse et al. 2010). This paper presents a review of the biogeography of the Llanos de Moxos and examines the explanatory power of the «domesticated landscape» hypothesis relative to the long-term natural processes in the region and its relevance to understanding Amazonia.

\section{Phytogeography of the Llanos de Moxos}

The Llanos de Moxos (also known as the Beni Savannas) are an enclave of open formations - herbaceous wetlands, grasslands, savannas, and woodlands - surrounded by the forests of the Upper Madeira basin (Fig. 1). NAVARro (2002) considered the Beni Savannas a unique biogeographic province within the BrazilianParanense Region, distinct from the Pantanal and Cerrado provinces, and not part of the Amazonian Region in a biogeographic sense. However, floristic endemism appears to be low; HANAGARTH \& BECK (1996) identified a total of 14 endemic vascular plant species in the Beni Savannas.

Typical Moxos landscapes include three vegetationtopography units: alturas, semialturas, and bajios (BECK 1983, Fig. 2). These are analogous to the «bancobajío-estero» sequence of the lower Orinoco Llanos. Alturas are uplands (natural levees) with forests of evergreen and deciduous species of genera such as Acacia, Albizia, Ampelocera, Anadenanthera, Attalea,
Bactris, Ceiba, Coccoloba, Ficus, Genipa, Guarea, Hura, Inga, Maclura, Margaritaria, Salacia, Spondias, Sterculia, Swartzia, Syagrus, Tabebuia, Trichilia, Triplaris, and Vitex (BeCK 1983; LANGSTROTH 1996).

Semialturas are levee backslopes and splays with brief, shallow inundations and vegetation contingent upon the fire regimes. Semialturas may support largely deciduous forest or woodland (genera such as Acrocomia, Astronium, Coccoloba, Copernicia, Cordia, Cupania, Enterolobium, Geoffroea, Guazuma, Piptadenia, Pithecellobium, Randia, Samanea, Sterculia, Tabebuia, and Zanthoxylum), Cerrado («campo cerrado» or «campo sujo», genera listed below), or pampa with scattered fire tolerant trees (Pseudobombax, Tabebuia) and Copernicia palms (BECK 1983; LANGSTROTH 1996). Termite mounds are frequent and present small woody islands with Celtis, Cereus, Coccoloba, Copernicia, Cordia, Machaerium, Rhamnidium, and Sorocea (Beck 1983; Langstroth 1996).

Bajíos are extensive seasonally inundated interfluvial basins dominated by grasses (e.g., Axonopus, Hymenachne, Leersia, Luziola, Paspalum, and Paratheria), and other herbaceous wetland genera such as Cyperus, Eichhornia, Eleocharis, Nymphaea, Pontederia, Rhynchospora, Scleria, and Thalia (BECK 1983; LANGSTROTH 1996).

Forest islands («islas») are prominent features of the Moxos landscapes and largely represent palaeolevee remnants surrounded by seasonally inundated bajios (Fig. 3 a and b). The islas are dominated by zoochorous taxa such as Attalea, Coccoloba, Ficus, Guarea, Guazuma, Nectandra, Rheedia, Salacia, Sterculia, Trichilia, and Vitex (ArTEAGA et al. 2006; LANGSTROTH 1996; Nutz 1995). These islands are analogous to the «matas» of the Orinoco and the «capões» of the Pantanal. Some forest islands were constructed by preColumbian peoples as occupational sites or developed from the colonization of trees upon abandoned raised fields, but these artificial islands are of minor significance compared to the vast number of natural levee fragment islands (LANGSTROTH 1996).

The dystrophic Neogene substrates of the dissected Forebulge and Precambrian Shield surfaces of the northern Beni support large areas of Cerrado vegetation with typical elements such as Bowdichia, Byrsonima, Callisthene, Caryocar, Curatella, Qualea, Salvertia, Vatairea, and Vochysia (HANAGARTh 1993; 


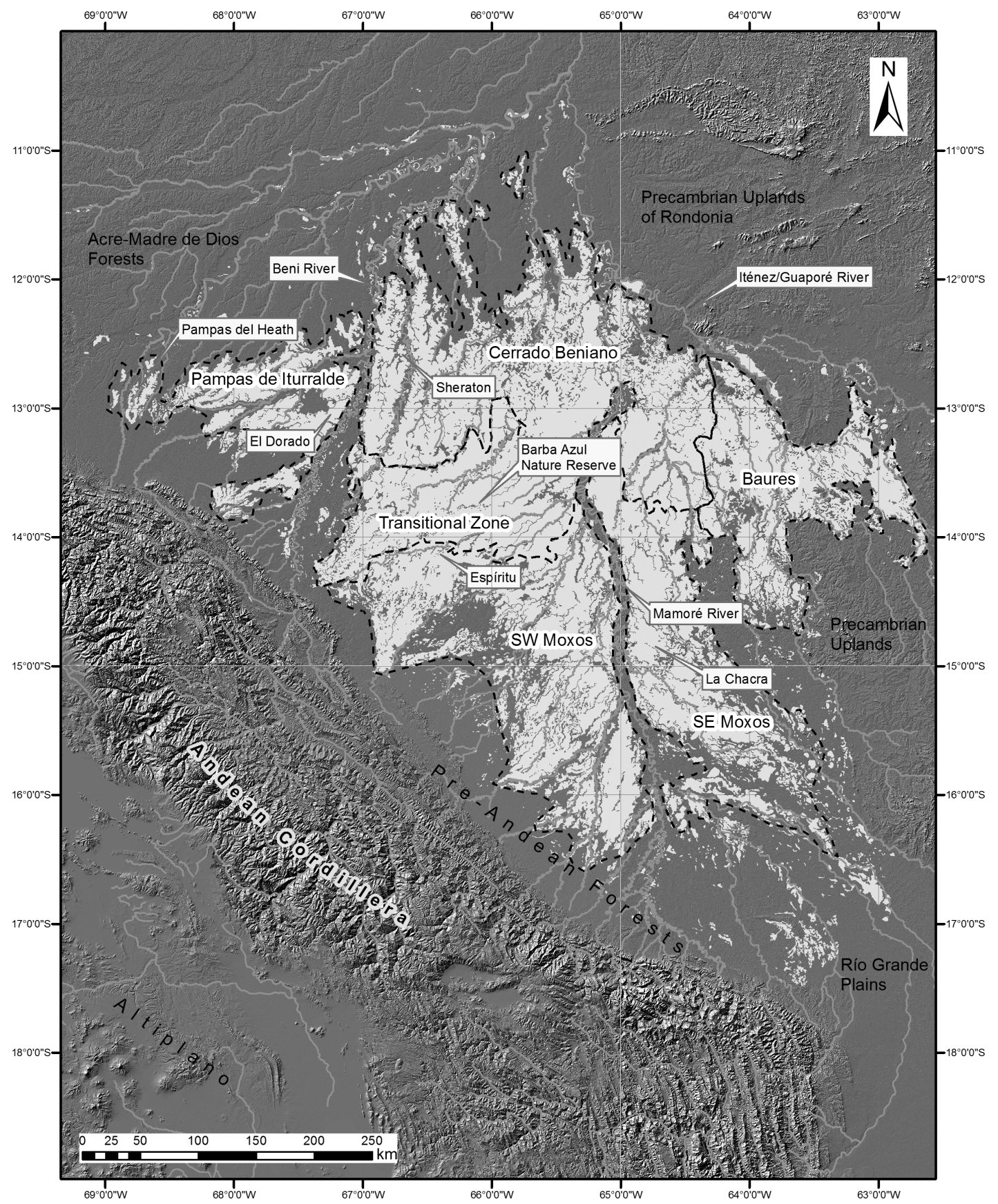

Fig. 1: Llanos de Moxos Region, indicating subregions and primary places mentioned in text Llanos de Moxos mit Subregionen und im Text erwähnten Lokalitäten

La région des Llanos de Moxos montrant les sous-régions et les lieux principaux mentionnés dans le texte Source: map composed by R. LANGSTroth; vegetation boundaries: NAVARro \& Ferreira 2007 


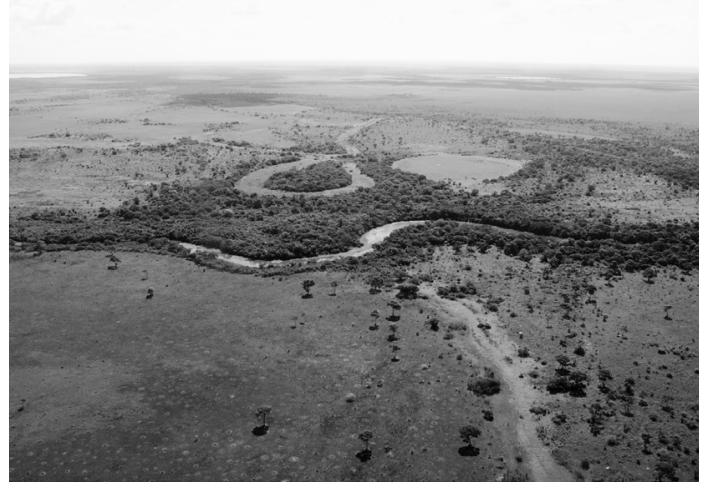

Fig. 2: Llanos de Moxos landscape with forested alturas, sparsely wooded semialtura, and open herbaceous bajio units corresponding to natural levees, backslopes and splays, and flood basins, respectively Llanos de Moxos mit bewaldeten Erhebungen, spärlich bewaldeten mittleren Höhenlagen und offenen krautreichen «bajíos». Das lokale Relief wird verursacht durch Dammufer, Schwemmfächer und Überflutungsbereiche. Paysage des Llanos de Moxos montrant les hauteurs boisées (alturas), les pentes d'altitudes moyennes faiblement boisées (semialtura) et les espaces herbeux ouverts (bajio) des bassins fluviaux

Photo: R. Langstroth, October 2009

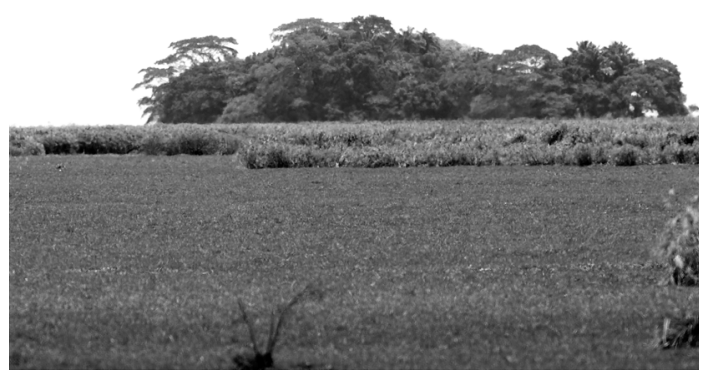

Fig. 3 a: Island in bajio with Cyperus giganteus and Thalia geniculata in foreground, La Chacra, Provinica Cercado

Waldinsel in einem «bajío» mit Cyperus giganteus und Thalia geniculata im Vordergrund, La Chacra, Provinz Cercado

Îlot forestier dans le bajío avec Cyperus giganteus et Thalia geniculata au deuxième plan (La Chacra, Province de Cercado)

Photo: R. LANGSTRoth, December 2003
NAVARro 2002). Forests in these dissected «upland» landscapes are limited to narrow stream valleys below the level of the savannas, rather than occurring upon positive relief features as in the southern Moxos landscapes (HANAGARTH 1993). A transitional belt occurs between the Cerrados of the Forebulge and the active whitewater floodbasins where the palaeochannels of the Beni river cut across the plains of southern Moxos, such as at the Barba Azul Nature Reserve (BANR) on the Omi river (Fig. 1 and 4).

The forests surrounding the Llanos de Moxos vary greatly in floristic composition and geoecological relationships, including humid Pre-Andean forests along the southwestern margins near the foothills of the Andes, seasonal Chiquitano dry forest and Guarayos transitional forests to the southeast, humid Iténez forests to the east, the Rondonian forests to the east, the Acrean forests to the north, and the Madre de Dios forests to the west. These variations in contact zones result in a great diversity of forest elements in the meander belt forests, gallery forests, and forest island archipelagos that traverse the Llanos de Moxos.

\section{Zoogeography of the Llanos de Moxos}

The Llanos de Moxos fauna includes both forest and open formation elements of diverse origins, including

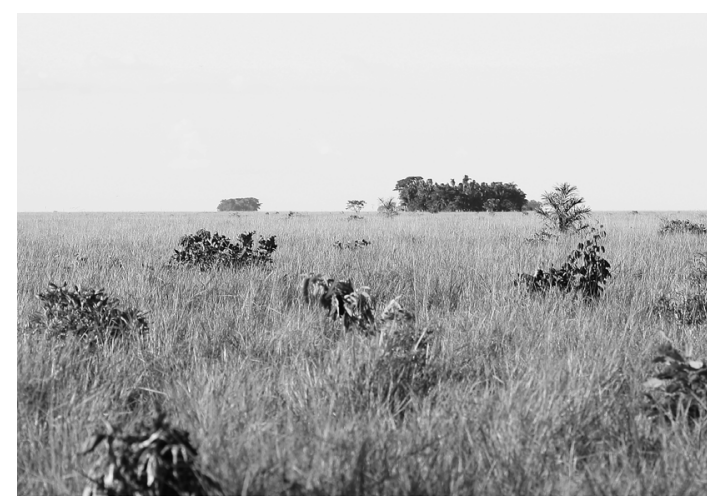

Fig. 3 b: Islands in worm-mound «sartenejal» grasslands, Campo sujo Cerrado grasslands in foreground, Barba Azul Nature Reserve

Waldinseln in «sartenejal» Grasland mit Wurmhügeln und Campo sujo Cerrado Grasland im Vordergrund, Barba Azul Naturreservat

Îlots forestiers avec monticules herbeux (sartenejal), prairies de Campo sujo Cerrado au deuxième plan, Réserve naturelle de Barba Azul

Photo: R. LANGSTROTh, October 2009 


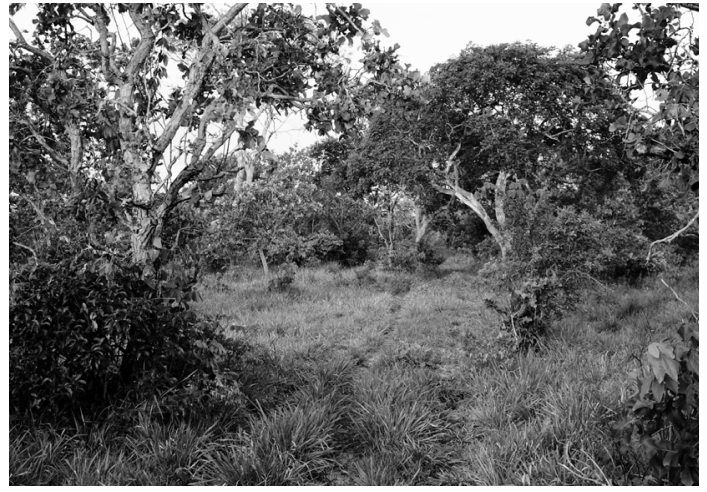

Fig. 4: Cerrado vegetation on semialtura of the Omi river, Barba Azul Nature Reserve, Yacuma Province, El Beni, Bolivia

Cerrado-Vegetation mittlerer Höhenlagen am OmiFluss, Barba Azul Naturreservat, Yacuma Provinz, El Beni, Bolivien

Végétation du Cerrado sur les hauteurs de la rivière Omi, Réserve naturelle de Barba Azul, Province de Yacuma, El Beni, Bolivie

Photo: R. Langstroth, October 2009

notable endemic vertebrates, which distinguish them from the Orinoco or Pantanal faunas. Moxos grasslands and savannas are inhabited by species from southern South American open-formations such as rheas (Rhea americana) and pampas deer (Ozotoceros bezoarticus), contrasting with ERICKSON's (2008) characterization of the region as being representative of as «Amazonia» (Fig. 5).

Despite supporting some of the highest amphibian diversity known for a Neotropical savanna (REICHLE 1997), there are no known amphibians endemic to the Llanos de Moxos or Beni Savannas. Dominant amphibians include widespread open formation species such as Leptodactylus fuscus, Rhinella schneideri, Rhinella major, and Pseudis boliviana.

The squamate fauna is also dominated by widespread open formation species from the Cerrado (Anolis meridionalis, Bothropoides matogrossensis, Kentropyx vanzoi), Chaco (Ophiodes intermedius, Tropidurus etheridgei, T. spinulosus), and widespread distributions (e.g., Ameiva ameiva, Tupinambis merianae, $T$. teguixin, Drymarchon corais, Hydrodynastes gigas, Mastigodryas bifossatus). An example of the Cerrado linkages in the central Llanos de Moxos is the presence of $K$. vanzoi at the BANR (Fig. 6). Prior to its discovery at the BANR in 2009 (personal observation),

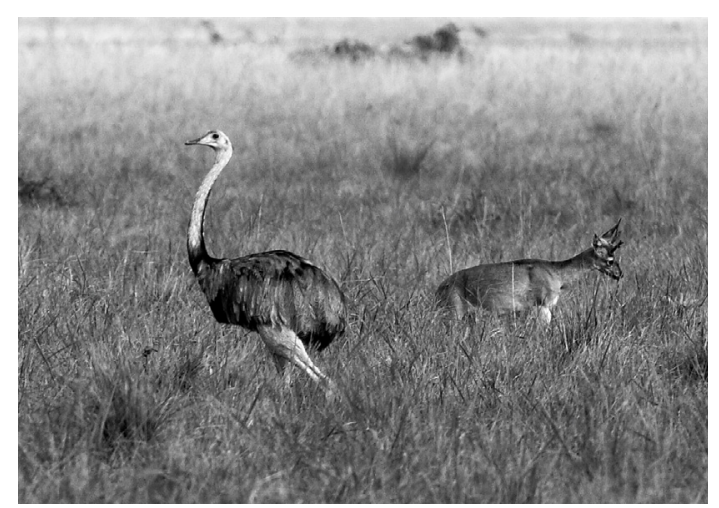

Fig. 5: Southern South American open formation fauna, Rhea americana and Ozoteceros bezoarticus, Barba Azul Nature Reserve, Yacuma Province, El Beni Fauna offener Vegetationsformationen des südlichen Südamerikas, Rhea americana und Ozoteceros bezoarticus, Barba Azul Naturreservat, Yacuma Provinz, El Beni Faune des formations végétales ouvertes méridionales de l'Amérique du Sud, Rhea americana et Ozoteceros bezoarticus, Réserve naturelle de Barba Azul, Province de Yacuma, El Beni

Photo: R. LANGSTROTh, October 2009

this lizard was known only from the Cerrados of the Precambrian Shield of Rondônia and Mato Grosso (Brazil) and the Serranía de Huanchaca in Santa Cruz (Bolivia) (Nogueira 2006). Werneck et al. (2009) date the divergence of this species in the Miocene, which supports the long-term presence of open-formations in central South America. The anaconda Eunectes beniensis is endemic to the flooded savannas and forests of the Beni.

The Llanos de Moxos support a diverse assemblage of birds, including important populations of threatened open-formation species such as Alectrurus tricolor, Culicivora caudacuta, and Coryphaspiza melanotis. Other noteworthy birds are Eleothreptus candicans and Laterallus xenopterus, known globally from a few disjunct localities in the Cerrados, as well as Alipiopsitta xanthops, Cyanocorax cristatellus, and Saltator atricollis (Herrera \& Maillard Z. 2007; Herrera \& Vidoz 2009). However, the most significant avifaunal element of the Llanos de Moxos is the blue-throated macaw (Ara glaucogularis), a critically endangered species that nests only in forest islands and is endemic to the Llanos de Moxos (Herrera et al. 2007). Molecular evidence suggests that $A$. glaucogularis and its widespread sister species $A$. ararauna diverged over 4 million years ago (Oliveira-Marques 2006). 


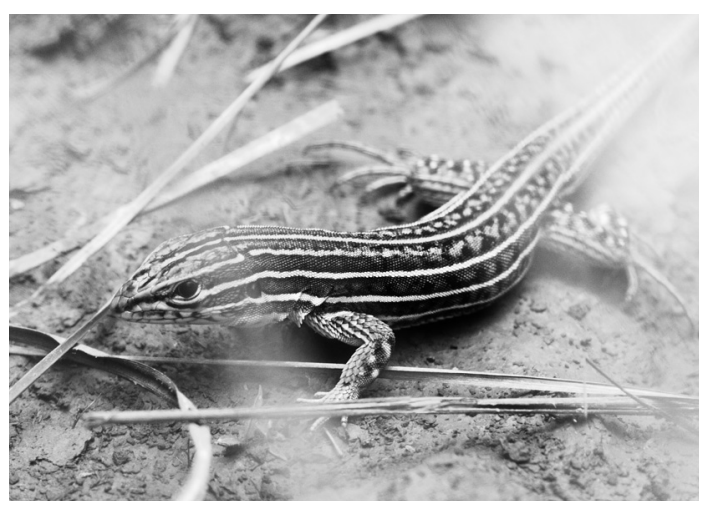

Fig. 6: Kentropyx vanzoi in grassland at Barba Azul Nature Reserve, Yacuma Province, El Beni, Bolivia Kentropyx vanzoi im Grasland des Barba Azul Naturreservates, Yacuma Provinz, El Beni, Bolivien

Kentropyx vanzoi dans les prairies de la Réserve naturelle de Barba Azul, Province de Yacuma, El Beni, Bolivie Photo: R. LANGSTRoth, October 2009

Widespread Cerrado (Chrysocyon brachyurus, Kunsia tomentosus), grassland (Blastocerus dichotomus, Euphractus sexcinctus, Ozotoceros bezoarticus), and habitat generalists (Hydrochoeris hydrochaeris, Panthera onca, Puma concolor, Tapirus terrestris, Tayussu pecari) are present. Cryptonanus unduaviensis is a micro-marsupial known only from wooded termite mound islands of the flooded savannas of the Llanos de Moxos and the Huanchaca region (Voss et al. 2005). The rat Hylaeamys acritus is known only from the savannas of the Beni and Santa Cruz departments of Bolivia (Emmons \& PATton 2005). The rats Juscelinomys guaporensis and J. huanchacae were described from the Huanchaca savannas (Emmons 1999) but are also in the Iténez savannas. In contrast to the Cerrado ties of the above, an unnamed clade of Calomys endemic to the Beni is most closely related to C. fecundus from the Subandean Chaco, not C. callosus of the Cerrados and Chiquitanía (Almeida et al.2007).

Extra-Amazonian dry forest primates are common such as Alouatta caraya, Aotus azarae, and Callicebus donacophilus in the woodlands, forest islands, and gallery forests of the Moxos region, as well as two endemic primates, the Beni titi monkey (Callicebus modestus) and the Olalla brothers' titi monkey $(C$. olallae). Vos (2006) identified divergence events for these latter species at approximately 6 million years and 3 million years, similar to the divergence time of the blue-throated macaws noted above. These characteristic elements of the Llanos de Moxos are clearly products of evolutionary histories linked to the rise of the Moxos savannas during the Miocene and the subsequent isolation of their forest habitats from surrounding source areas, and not consequences of landscape domestication.

The presence of Cerrado lizards and small rodents, species with relatively low dispersal abilities across forest barriers, in isolated savannas of the Southwestern Amazon Basin suggests an ancient connectivity with the Precambrian Shield region to the east. Late Miocene environments of the southwestern Amazon basin were dominated by grasslands, swamps, and gallery forests, with seasonal climates and hyper-avulsive rivers, similar to the modern Llanos de Moxos (Latrubesse et al. 2010; PlotzKi et al. 2011). These early non-forest ecosystems were likely in contact with the open-formations of the Precambrian Shield region in the past. The development of forest corridors along the major rivers such as the Iténez (Guaporé) and the Beni occurred only after these rivers established their present meander belts.

\section{Subregional differentiation of the Llanos de Moxos}

Hanagarth \& Beck (1996), Hanagarth \& SzwagrZAK (1998), and NAVArro (2002) have identified a major biogeographic division of the Beni savannas into northern and southern zones, which correspond to the Beni Cerrados and the Llanos de Moxos sensu stricto, respectively. Additional subregions are evident, each with unique characters that reflect natural variations in the geology, water and sediment chemistry, erosional and depositional regimes, climate, and other physical factors that affect vegetation, fauna, and land uses by the peoples who settled these landscapes (Fig. 1).

The southwestern region (SW Moxos) between the Beni and Mamoré rivers is influenced by rivers which carry base- and salt-rich Andean sediments, as evidenced by the abundance of Copernicia palms and an absence of Mauritia palms. Vegetation at Espíritu (Fig. 1) is floristically more similar to the Pantanal than to the nearby Iturralde pampas or Cerrados on the Bolivian Precambrian Shield (Hanagarth \& Beck 1996). SW Moxos includes many archaeological raised fields and causeways and is presently densely populated by indigenous peoples, Andean colonists, and cattle ranches, presumably linked to the availability of young alluvial soils derived from whitewater rivers (Lombardo et al. 2011). Flooding in this subregion is also greater in magnitude and frequency, which is also likely related to the abundance of earthworks constructed as flood-avoidance strategies as suggested by LOMBARDO et al. (2010). 


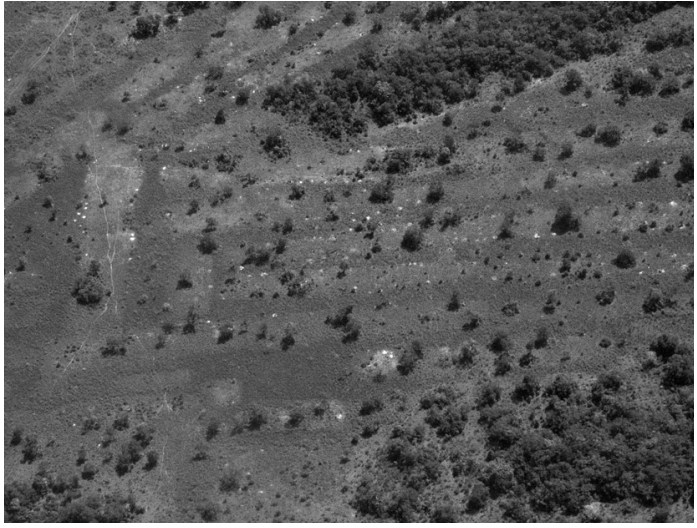

Fig. 7: Abandoned raised fields colonized by shrubs and trees in Cerrado savannas near Iruyáñez River, Yacuma Province, El Beni. White spots are termite mounds.

In der Nähe des Iruyáñez-Flusses, Yacuma Provinz, El Beni, sind aufgelassene Hügelbeete durch Büsche und Bäume der Cerrado-Savanne besiedelt. Weisse Flecken sind Termitenhügel.

Champs surélevés abandonnés et colonisés par les broussailles et les arbres dans les savanes du Cerrado près de la rivière Iruyáñez, Province de Yacuma, El Beni. Les points blancs sont des termitières.

Photo: U. BÜCHLER, 2005

To the north of SW Moxos lies a Transitional Zone traversed by SW-NE to E-W trending palaeochannels related to the migration of the Beni river (HANAGARTH 1993). Small, underfit rivers such as the Omi occupy portions of these palaeochannels. The interfluvial zones between these palaeochannels are not subjected to recent sedimentation and the soils are strongly leached, especially on the alturas and semialturas where the vegetation takes on a strong Cerrado character (Fig. 4).

Further north, the land is higher due to the deformation of the underlying Precambrian Shield, creating a feature known as the Beni Forebulge. These higher surfaces are dissected by streams and while not subject to sedimentation are occasionally inundated by rainwater ponding on the flat interfluves. This subregion comprises the heart of the Beni Cerrados that occupy an area of nearly $27,200 \mathrm{~km}^{2}$ (IBISCH et al. 2008). East of the Mamoré, Cerrados occupy interfluvial uplands of the San Ramón-San Joaquín district where the soils are rich in ferralitic concretions («cascajo»). The woody species at Sheraton (Fig. 1) include all of the 27 most common Cerrado species of Brazil and 90\% of the 65 species from a Cerrado near Cuiabá, Brazil (Hanagarth \& Beck 1996). Despite the dystrophic soils of the Cerrado, the largest raised fields are actually in this subregion, not in the Llanos de Moxos sensu stricto, and the abandoned platforms presently support woody species intolerant of waterlogged soils (Fig. 7).

The northeastern boundary of the Llanos de Moxos is formed by the Iténez (Guaporé) river that drains the Precambrian uplands of Rondônia and Santa Cruz (PlotzKi et al. 2011). The Baures subregion occupies the plains of the southern Iténez basin and is characterized by a combination of whitewater, blackwater, and clearwater rivers. While there are few raised fields (e.g., $12.8 \mathrm{~km} \mathrm{NW}$ of Bella Vista, $13.200417^{\circ} \mathrm{S}, 63.793976^{\circ} \mathrm{W}$ ), there are many elaborate earthworks such as ringed mounds and zigzag causeways. The forest islands in the Baures region are generally lateritic uplands within a flooded herbaceous savanna mosaic. In contrast to the true Moxos subregion, Mauritia palms are prevalent in the permanently waterlogged acidic soils of the Baures region. While data on the biota of the Baures open formations are nearly inexistent, significant aspects of the Baures subregion include large populations of giant otters and marsh deer, a result of the historically low human population density in these remote and wet savannas. Precambrian rock outcrops of the Baures subregion such as Cerro Orícore and the Serranía de San Simón are likely to harbor undescribed endemic elements, particularly Tropidurus lizards (personal observation).

The southeastern zone of the Llanos de Moxos (SE Moxos) between the Mamoré and San Pablo rivers has a complex Quaternary fluvial history (related to the migration of the Río Grande), resulting in a mosaic of savannas, palaeolevee forests, and partiallyinfilled oriented lakes. SE Moxos presents the greatest concentration of large earthmound complexes (e.g., Ibiato, Ibibate, Casarabe, Perro Muerto, etc.), largely upon naturally elevated, forested palaeolevees, not in savannas (LANGSTRoth 1996; LOMBARDo \& PrüMERS 2010). The soils are formed from Andean sediments of the Río Grande basin and are consequently relatively rich in bases and have high salt contents as evidenced by the abundance of Copernicia palm savannas. The extensive semialtura woodlands and natural levee forests of SE Moxos are dominated by dry forest elements such as Anadenanthera colubrina, Astronium fraxinifolium, Cordia glabrata, Piptadenia robusta, and Sterculia apetala, indicating their connectivity with the Chiquitano dry forests (LANGstroth 1996). The abundance of natural levee surfaces with fertile, well drained soils suitable for upland agriculture may well explain the near-absence of archaeological raised field 
sites in this region as suggested by Lombardo et al. (2010), as well as the recent boom in agricultural colonization and deforestation along the Trinidad-Santa Cruz highway.

The savannas west of the Beni River in the departments of La Paz (Bolivia) and Madre de Dios (Peru) are a distinct subregion that includes the Pampas del Heath and the Pampas de Iturralde. The savannas at El Dorado share nearly as many plant species with the Cerrados (21\% Sørensen index) as with nearby Espíritu (22\% Sørensen index) (Hanagarth \& BecK 1996). Mamani et al. (2010) note that the Pampas del Heath are floristically distinct from the «Cerrado de Ixiamas», the former having only two Cerrado species but the latter with high Cerrado affinity. While these savannas support Blastocerus, Chrysocyon, Kunsia, and Ozotoceros, other widespread savanna faunal elements such as Rhea and Tropidurus appear to be absent. The Pampas de Heath and the Pampas de Iturralde bear no evidence of archaeological earthworks and have been occupied historically by forest-dwelling peoples (Denevan 1966, 1980).

\section{Llanos de Moxos as «domesticated landscape» and its relevance to understanding of «Amazonia»}

ERICKSON (2008) supports his «domesticated landscape» argument largely on his research in savanna landscapes of the Llanos de Moxos. As demonstrated above, the Llanos de Moxos are not typical of «Amazonia» in any ecological or biological sense and cannot be considered «Amazonian» except in a watershed sense. Any generalization about «Amazonia» based on the Llanos de Moxos is thus inherently flawed and inaccurate. However, the major pre-Columbian population centers of the Amazon basin were located in the seasonal peripheries or flooded savannas, not in the center of the humid forests (Bush \& Silman 2008; Meggers 2003). Rather than supporting arguments for agricultural intensification and high population in Amazonian forests, the evidence from the Llanos de Moxos and other savanna and wetland landscapes such as Marajó Island, the Coastal Savannas of the Guianas, and the Alto Xingu region were areas that provided greater opportunities for the development of intensive landscape management in the tropical lowlands of South America.

ERICKSON (2008) does not imply that species were domesticated in Moxos but rather that the landscape itself was reorganized and improved for the needs of the people who inhabited it. In reality, there is little to suggest that the Llanos de Moxos ecosystems are managed systems or even feral systems, or by any other means garden-like in nature, despite the existence of numerous archaeological earthworks of great cultural significance. These earthworks are situated in landscapes which are the result of Neogene geology of the Andean Foreland Basin, the impermeability of the sedimentary cover, and the highly seasonal rainfall regime. Despite the large number of earthworks and the extensive use of fire, the overall configuration of wetland and upland ecosystems in Moxos is not determined by human agency. On finer scales, the vegetation may locally be influenced by earthworks, but more often reflects natural relief, including features created by earthworms, ants, termites, cattle, and plants themselves (MAYLE et al. 2007).

The most significant long-term human impacts on the ecology and biodiversity of the Llanos de Moxos are the introduction of cattle in 1682 and the advance of the fossil fuel powered agricultural frontier in the first decade of the $21^{\text {st }}$ century. However, even the sunflower, rice, and soybean fields will eventually be abandoned just as the pre-Columbian raised fields and Jesuit-era cotton fields were abandoned before them. The natural processes which define the landscapes and ecology - inundation, drought, and fire - will likely return the transformed landscapes back to wetlands, savannas, and forests inhabited by largely native species of flora and fauna, along with the cattle.

Despite the construction of elaborate earthworks, the use of fire, hunting, the introduction of cattle, and agricultural land conversion humans have not significantly altered the essential structure, function, or spatial organization of the physical and biological systems of the Llanos de Moxos landscapes. The species assemblages continue to be dominated by native species, many with origins in the Miocene and Pliocene that pre-date the dispersal of hominids out of Africa, let alone the arrival of humans in the Americas. The biodiversity and biogeography of the Llanos de Moxos cannot be explained as an artifact of landscape domestication or the biological colonization of abandoned earthworks. In contrast, the past and present patterns of human settlement and utilization of the Moxos landscapes are more significantly associated with the natural patterns of inundation, drainage, soils composition, and biological resources.

\section{Literature cited}

Almeida, F.C., Bonvicino, C.R. \& P. CordeiroEstrela (2007): Phylogeny and temporal diversification of Calomys (Rodentia, Sigmodontinae): Implications for the biogeography of an endemic genus of the open/dry biomes of South America. - In: Molecular Phylogenetics and Evolution 42, 2: 449-466. 
Arteaga, L.L., Aguirre, L.F. \& M.I. Moya (2006): Seed rain produced by bats and birds in forest islands in a neotropical savanna. - In: Biotropica 38, 6: 718-724.

BECK, S.G. (1983): Vegetationsökologische Grundlagen der Viehwirtschaft in den Überschwemmungs-Savannen des Río Yacuma (Departamento Beni, Bolivien). - Dissertationes botanicae 80, Vaduz: Cramer.

Bush, M.B. \& M.R. Silman (2008): Amazonian exploitation revisited: ecological asymmetry and the policy pendulum. - In: Frontiers in Ecology and the Environment 5, 9: 457-465.

Denevan, W.M. (1966): The aboriginal cultural geography of the Llanos de Mojos of Bolivia. - IberoAmericana 48, Berkeley, Los Angeles: University of California Press.

Denevan, W.M. (1980): The Rio Heath savannas of southeastern Peru. - In: Geoscience and Man 21: 157163.

Emmons, L.H. (1999): Two new species of Juscelinomys (Rodentia: Muridae) from Bolivia. - In: American Museum Novitates 3280: 1-15.

Emmons, L.H. \& J.L. Patton (2005): A new species of Oryzomys (Rodentia: Muridae) from Eastern Bolivia. - In: American Museum Novitates 3478: 1-26.

ERICKSON, C.L. (2008): Amazonia: the historical ecology of a domesticated landscape. - In: Silverman, H. \& W.H. Isbell (ed.): Handbook of South American archaeology. - New York: Springer: 157-183.

Hanagarth, W. (1993): Acerca de la geoecología de las sabanas del Beni. - La Paz: Instituto de Ecología.

Hanagarth, W. \& S.G. BecK (1996): Biogeographie der Beni-Savannen (Bolivien). - In: Geographische Rundschau 48, 11: 662-668.

Hanagarth, W. \& A. SzWAgrzaK (1998): Geoecology and biodiversity: problems and perspectives for the management of natural resources of Bolivia's forest and savanna ecosystems. - In: BARTHLOTt, W. \& M. WinIGER (eds): Biodiversity: a challenge for development research and policy. - Berlin: Springer: 289-312.

Herrera, M. \& O. Maillard Z. (2007): Registros significativos de aves para el Departamento de Beni, Bolivia. - In: Kempffiana 3, 1: 28-34.

Herrera, M., Vargas, H., Sandoval, V., Perskin, T. \& O. Rendón (2007): Nuevo dato en la distribución de la paraba barba azul (Ara glaucogularis). - In: Kempffiana $3,1: 1-24$.

Herrera, M. \& J.Q. Vidoz (2009): Registros significativos de aves para el Departamento del Beni, Bolivia: Parte 3. - In: Kempffiana 5, 1: 65-71.

Hoorn, C., Wesselingh, F.P., Ter Steege, H., Bermudez, M.A., Mora, A., Sevink, J., Sanmartín, I., Sanchez-Meseguer, A., Anderson, C.L., Figueiredo, J.P., Jaramillo, C., Riff, D., Negri, F.R., Hooghiemstra, H., Lundberg, J., Stadler, J., Sarkinen, T. \& A. Antonelli (2010): Amazonia through time: Andean uplift, climate change, landscape evolution, and biodiversity. - In: Science 330, 6006: 927-931.
Ibisch, P.L., Beck, S.G., Gerkmann, B. \& A. Carretero (2008): Ecoregiones y ecosistemas. - In: IBISCH, P.L. \& G. MÉRIDA (ed.): Biodiversidad: la riqueza de Bolivia. - Santa Cruz de la Sierra: Fundación Amigos de la Naturaleza: 47-88.

LANGStroth, R.P. (1996): Forest islands in an Amazonian savanna of Northeastern Bolivia. - Unpublished Ph.D. dissertation, Madison: University of Wisconsin, Department of Geography.

Latrubesse, E.M., Cozzuol, M., Da Silva-Caminha, S.A.F., Rigsby, C.A., AbsY, M.L. \& C. Jaramillo (2010): The Late Miocene paleogeography of the Amazon Basin and the evolution of the Amazon River system. - In: Earth-Science Reviews 99, 3-4: 99-124.

Lombardo, U., Canal-Beeby, E., Fehr, S. \& H. Veit (2010): Raised fields in the Bolivian Amazonia: a prehistoric green revolution or a flood risk mitigation strategy? - In: Journal of Archaeological Science 38, 3: 502-512.

Lombardo, U. \& H. Prümers (2010): Pre-Columbian human occupation patterns in the eastern plains of the Llanos de Moxos, Bolivian Amazonia. - In: Journal of Archaeological Science 37, 8: 1875-1885.

Lombardo, U., Canal-Beeby, E. \& H. Veit (2011): Eco-archaeological regions in the Bolivian Amazon. An overview of pre-Columbian earthworks linking them to their environmental settings. - In: Geographica Helvetica 66, 3:173-182.

Mamani, F., Pozo, P., Soto, D., Villarroel, D. \& J.R.I. Wood (2010): Libro rojo de las plantas de los cerrados del Oriente Boliviano. - Santa Cruz de la Sierra: Museo de Historia Natural Noel Kempff Mercado, Darwin Initiative, http://www.darwincerradosdebolivia. org/docs/libro_rojo_cerrados_bolivia.pdf 4.1.2011.

Mayle, F.E., Langstroth, R.P., Fisher, R.A. \& P. MEIR (2007): Long-term forest-savannah dynamics in the Bolivian Amazon: implications for conservation. - In: Philosophical Transactions of the Royal Society B-Biological Sciences 362, 1478: 291-307.

MegGers, B.J. (2003): Natural versus anthropogenic sources of Amazonian biodiversity: the continuing quest for El Dorado. - In: Bradshaw, G.A. \& P.A. MARQuet (eds): How landscapes change. - Berlin: Springer: 89-107.

NAVARRo, G. (2002): Provincias biogeográficas del Beni y del Pantanal. - In: Navarro, G. \& M. Maldonado (eds): Geografía ecológica de Bolivia: vegetación y ambientes acuáticos. - Cochabamba: Centro de Ecología Simón I. Patiño: 157-193.

Navarro, G. \& W. Ferreira (2007): Mapa de vegetación de Bolivia. - http://conserveonline.org 10.1.2010. Nogueira, C. De C. (2006): Diversidade e padrões de distribuição da fauna de Lagartos do Cerrado. Unpublished doctoral dissertation, São Paulo: Instituto de Biociências da Universidade de São Paulo.

Nutz, L. (1995): Untersuchungen zur Sukzession von Inselwäldchen der Feuchtsavanne des Beni-Tieflandes 
Bolivien. - Karlsruher Berichte zur Geographie und Geoökologie 6, Karlsruhe: Institut für Geographie und Geoökologie.

Oliveira-Marques, A.R. (2006): Filogenia molecular das espécies do Gênero Ara (Psittaciformes, Aves). Unpublished master's thesis, São Paulo: Instituto de Biociências da Universidade de São Paulo.

Plotzki, A., May, J.-H. \& H. Vert (2011): Review of past and recent fluvial dynamics in the Beni lowlands, NE Bolivia. - In: Geographica Helvetica 66, 3: 164-172. Reichle, S. (1997): Diversidad de anfibios en la Estación Biológica del Beni. - In: Memorias del Primer Congreso Internacional Investigación y Manejo en la Reserva de la Biosfera Estación Biológica del Beni, Trinidad, 2 al 6 de diciembre, 1996, La Paz: Estación Biológica del Beni: 77-78.

Vos, R.A.(2006): Inferring large phylogenies: the big tree problem. - Unpublished Ph.D. dissertation, Burnaby: Simon Fraser University, Department of Biological Sciences.

Voss, R.S., Lunde, D.P. \& S.A. JANSA (2005): On the contents of Gracilinanus Gardner and Creighton, 1989 , with the description of a previously unrecognized clade of small didelphid marsupials. - In: American Museum Novitates 3482: 1-34.

Werneck, F.P., Giugliano, L.G., Collevatti, R.G. \& G.R. Colli (2009): Phylogeny, biogeography and evolution of clutch size in South American lizards of the genus Kentropyx (Squamata: Teiidae). - In: Molecular Ecology 18, 2: 262-278.

\section{Acknowledgements}

This research in the Llanos de Moxos was funded by the National Science Foundation Doctoral Dissertation Award SBR-9305629 and through the generosity of Fernando Velasco Cuéllar, Asociación Armonía, American Bird Conservancy, World Land Trust-US, and Loro Parque Fundación.

\section{Abstract: Biogeography of the Llanos de Moxos: natural and anthropogenic determinants}

The Llanos de Moxos are an enclave of non-forest biota in the Amazonian lowlands of Bolivia where elements from the Gran Chaco, the Cerrados, and other source areas inhabit landscapes where indigenous peoples created numerous earthworks. While local relief features and geomorphology are often, at least in part, a result of pre-Hispanic human agency, the general patterns of biological diversity in the Llanos de Moxos are determined by longer histories of climatic, geologic, fluvial, and biological processes that well predate the human presence. The flora and fauna of the Moxos wetlands, grasslands, and savannas include many elements from the Cerrados and other extra-Amazonian open formations. While the flora shows low levels of endemicity, the fauna includes several endemic vertebrates associated with forest islands. The Moxos biota largely dates back to the Miocene. In terms of human impact, the introduction of cattle and cattle ranching is likely the most significant event in terms of the present-day landscape and ecology.

Keywords: Llanos de Moxos, biodiversity, biogeography, savannas, forest islands

\section{Zusammenfassung: Biogeographie der Llanos de Moxos: natürliche und anthropogene Ursachen}

Die Llanos de Moxos sind eine waldfreie Enklave im Amazonas-Tiefland Boliviens, in der biotische Elemente aus dem Gran Chaco, den Cerrados und anderen Ursprungsregionen in Gebieten auftreten, in denen frühere Kulturen zahlreiche Erdbauten hinterlassen haben. Während das lokale Relief und die Oberflächenstrukturen oft zumindest teilweise präkolumbischen anthropogenen Ursprungs sind, wird das generelle Muster der Biodiversität in den Llanos de Moxos vor allem durch die längere Entwicklung von Klima, Geologie sowie fluvialen und biologischen Prozessen bestimmt, die deutlich älter sind als das Auftreten der Menschen in diesem Raum. Flora und Fauna der Sumpfgebiete, der Grasländer und Savannen beinhalten viele Elemente der Cerrados und anderer ausser-amazonischer Formationen. Während die Flora einen niedrigen Grad an Endemismus zeigt, ist die Fauna durch das Auftreten von verschiedenen endemischen Vertebraten auf den Waldinseln gekennzeichnet. Die Lebewelt in den Llanos de Moxos hat Ursprünge bis zurück ins Miozän. Hinsichtlich des menschlichen Einflusses ist das Einführen von Vieh und die Errichtung von Viehfarmen wahrscheinlich der bedeutendste Eingriff in die Landschaft.

Schlüsselwörter: Llanos de Moxos, Biodiversität, Savanne, Waldinseln

\section{Résumé: Biogéographie des Llanos de Moxos: causalité naturelle et anthropogène}

Les Llanos de Moxos sont une enclave non forestière dans les basses terres amazoniennes peuplées de certains éléments biologiques du Gran Chaco, des Cerrados et d'autres régions et où les peuples indigènes construisirent de nombreux terrassements. Alors que le relief et la géomorphologie locale sont souvent le résultat, au moins en partie, d'une action anthropogène précolombienne, la diversité biologique des Llanos de Moxos est déterminée par des processus climatiques, fluviaux et biologiques de long terme qui précèdent de loin l'installation humaine dans la région. La flore et la faune des zones humides, des prairies et des savanes comprennent plusieurs éléments venant des Cerrados et d'autres formations ouvertes extra-amazoniennes. Alors que la flore présente de faibles niveaux d'endé- 
misme, la faune comprend plusieurs espèces de vertébrés endémiques associés aux îlots forestiers. L'origine de la biodiversité des Moxos est largement à trouver dans l'époque miocène. L'introduction du bétail et de l'élevage en ranch est certainement l'événement ayant eu l'impact le plus significatif sur le paysage et l'écologie.

Mots-clés: Llanos de Moxos, biodiversité, biogéographie, savanes, îlots forestiers

Dr. Roberto Langstroth Plotkin, ENVIRON International, 1401 New York Ave NW, Suite 1225, Washington, DC, 20005 USA.

e-mail:pampa_isla@yahoo.de

Manuskripteingang/received/manuscrit reçu le 18.4.2011

Annahme zum Druck/accepted for publication/accepté pour publication: 14.10 .2011 